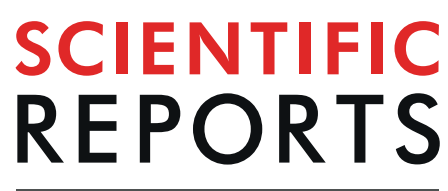

natureresearch

Check for updates

\title{
Soil invertebrate diversity loss and functional changes in temperate forest soils replaced by exotic pine plantations
}

\begin{abstract}
Camila Cifuentes-Croquevielle ${ }^{1,2,6 \bowtie}$, Daniel E. Stanton ${ }^{3}$ \& Juan J. Armesto ${ }^{1,2,4,5,7}$
The global expansion of tree plantations is often claimed to have positive effects for mitigating global warming, preventing soil erosion, and reducing biodiversity loss. However, questions remain unanswered about the impacts of plantations on belowground diversity and soil properties. Here, we examine how forestry plantations of exotic trees affect critical soil functions and the composition of invertebrate assemblages, by comparing invertebrate diversity and soil physico-chemical properties between non-native Pinus radiata plantations, and nearby native forests in a region of extensive plantation activity in south-central Chile. We quantified differences in diversity, abundance, and community composition of soil invertebrates, as well as fundamental soil properties such as soil water content, water infiltration, nutrient status, and pH. We show that in this landscape mosaic of native forest and plantations, both soil invertebrate communities and physical soil properties differed significantly between systems, despite similar soil origins and topographies. We found a significant loss of soil carbon and a major reduction in taxonomic and functional diversity of soil invertebrates in pine plantation sites. Soil biotic and abiotic characteristics of plantations differed significantly from native forests in plantation-dominated south-central Chile, with profound consequences for ecosystem processes and resilience to future climate change.
\end{abstract}

Anthropogenic land cover change is considered one of the main drivers of global change in the $21^{\text {st }}$ century ${ }^{1-3}$. Since 1990, four million hectares of primary native forest have been globally lost, while at the same time the area of exotic tree plantations -which are primarily for timber and fiber production- has increased at a rate of $2 \%$ per year, accumulating 264 million hectares by 2010 , and is expected to reach 300 million ha by $2020^{4}$. Forestry is often based on a production model that resembles agroecosystems, with costly anthropogenic subsidies and limited concerns for biodiversity loss ${ }^{5}$. In many countries having transitions from Mediterranean- to temperate climate (e.g., Chile, South Africa, Spain, New Zealand) vast plantations of Pinus radiata and several Eucalyptus species, have replaced the original forests ${ }^{3,6}$. Among the ecological consequences of the substitution of diverse native forest by massive plantations of a single exotic (non-native) timber species, is the loss of biological species richness both above and belowground, leading to a general process described as biotic homogenization ${ }^{7-9}$. Because of biotic homogenization, local species assemblages become depauperate, as less common and often native species tend to disappear ${ }^{10}$, while other species, most often non-native ones, become widespread and dominant. Biotic homogenization can also be related to the loss of specialized functional groups and the expansion of generalist, widespread species ${ }^{9}$, giving way to novel floristic assemblages $\left(\operatorname{sensu} \operatorname{Hobbs}^{11}\right)$.

Global analyses of changes in forest cover often assume potential ecological equivalence between tree plantations and the original native forests, in terms of carbon sequestration and forest productivity ${ }^{12,13}$. However, few studies have evaluated the direct impacts of large-scale replacement of native forest by exotic tree plantations on

${ }^{1}$ Instituto de Ecología y Biodiversidad, Alameda 340, Santiago, Chile. ${ }^{2}$ Universidad de Chile, Facultad de Ciencias, Santiago, Chile. ${ }^{3}$ Department of Ecology, Evolution and Behavior, University of Minnesota-Twin Cities, Saint Paul, MN, USA. ${ }^{4}$ Cary Institute of Ecosystem Studies, Millbrook, New York, USA. ${ }^{5}$ Departamento de Ecología, Facultad de Ciencias Biológicas, Pontificia Universidad Católica de Chile, Alameda 340, Santiago, Chile. ${ }^{6}$ Instituto de Filosofía y Ciencias de la Complejidad, Santiago de Chile, Chile. ${ }^{7}$ Facultad de Ciencias Naturales y Oceanográficas, Universidad de Concepción, Concepción, Chile. ${ }^{\circledR}$-mail: camila.cifuentes@gmail.com 


\begin{tabular}{|l|l|l|}
\hline Country & $\begin{array}{l}\text { Estimated area } \\
(\mathbf{h a} \times \mathbf{1 0 0 0})\end{array}$ & $\begin{array}{l}\text { New area or loss } \\
(\mathbf{h a} \times \mathbf{1 0 0 0} / \mathbf{y r})\end{array}$ \\
\hline Australia & $773(2010)$ & 1.5 \\
\hline Chile & $1478(2009)$ & 11.5 \\
\hline Ecuador & $20(1990)$ & $\mathrm{ND}$ \\
\hline New Zealand & $1545(2011)$ & -11 \\
\hline Italy & $6(2005)$ & 0 \\
\hline Spain & $287(2006)$ & $\mathrm{ND}$ \\
\hline South Africa & $57(2008)$ & -2 \\
\hline Argentina & $5.5(2011)$ & 0 \\
\hline Others & 35 & $\mathrm{ND}$ \\
\hline Total & 4207 & -1 \\
\hline
\end{tabular}

Table 1. Estimated areas Pinus radiata plantations around the world and the average annual change in area for the period 2008 and 2013 (data from: Mead, 2013). *The year of estimate is given in brackets. ND= No data for the period.

belowground invertebrate communities and on associated soil properties that, in turn, affect productivity and ecosystem functions aboveground ${ }^{14}$.

Evidence has shown that plant species composition determines local environmental conditions such as light incidence, temperature, soil moisture and substrate chemical quality that becomes later incorporated as detritus ${ }^{15}$. Furthermore, it has been reported that plant diversity is positively correlated with invertebrate diversity ${ }^{16-18}$. In addition, plant specific physiological traits, as litter production, defensive compounds or nutrient efficiency, have a strong effect on the rate at which soil communities perform decomposition ${ }^{19,20}$. Accordingly, plant species composition and soil communities are tightly related, as plants determine the quality and quantity of litter inputs available to soil communities. The loss of soil functions belowground is hard to perceive visually, but field studies have suggested strong deteriorating effects of land cover change on carbon storage, nutrient retention, and water provision $^{9,21,22}$. All of these are significant ecosystem benefits contributing to human wellbeing ${ }^{23}$.

Soil invertebrates perform a wide range of functions that contribute to ecosystem health, through the maintenance of nutrient cycling, water storage and primary productivity ${ }^{24}$. Soil invertebrates directly or indirectly affect organic matter decomposition, the maintenance of soil structure, and can exert direct influence on plant communities through selectively feeding on roots, leaves or seeds ${ }^{25}$. As aboveground trophic chains are sustained by autotrophic primary production, the breakdown of belowground dead organic material performed by soil organisms, including decomposers and detritivores, provides the central input of nutrients and energy for soil processes ${ }^{24}$. As soils accumulate nutrients and energy through decomposition, soil communities expand and become more complex. Moreover, previous work has documented the positive interactions and feedbacks between soil invertebrates and soil microorganisms ${ }^{24}$ that contribute to this complexity.

Given the lack of comparative research on the soil biota and its functions in native forests and exotic forestry plantations, this work reports changes in soil invertebrate diversity and community composition between native forests and areas where the original forests were replaced by forestry plantations in El Maule region $\left(35^{\circ} \mathrm{S}\right)$, in central Chile. This shift in land cover has been recurrent across extensive areas of central Chile beginning in the second half of the $20^{\text {th }}$ century ${ }^{26}$. In this work, we expected to identify invertebrate groups that could be useful biological indicators of soil ecological status in these two systems. To assess the functional connections between the composition of soil organisms ${ }^{27}$ and soil physical and chemical properties related to water and nutrient conservation, we measured these soil functions along with the assessment of the characteristics of soil biotic assemblages. Because of the importance of native and non-native forest cover, and particularly forest soils in mitigating climate change ${ }^{28}$, we also discuss the data on soil carbon storage in the context of the reported expansion of plantations in Chile and Mediterranean-climate regions elsewhere.

Because of its versatile requirements, fast-growing habit, and the production of medium-density softwood, suitable for a wide range of end-uses, from soil erosion control to construction and energy production ${ }^{21}$ Pinus radiata plantations have become widespread, particularly in New Zealand, Chile, Australia and Spain (Table 1). However, some environmental impacts associated with biotic homogenization of landscapes due to pine silviculture, such as the rate of spread of high-intensity fires ${ }^{29,30}$, soil nutrient losses, and water depletion are also well documented ${ }^{31-35}$. Therefore, our hypothesis is that pine plantation soils have become significantly less fertile (i.e. have lower nutrient concentrations, less water infiltration capacity, and are more acid and compacted) than native forest soils; which, in turn, is accompanied by a reduction in soil invertebrate diversity and changes in the assemblage composition, leading to a process of biotic homogenization. Based on this evidence, the notion of pine plantations as sustainable ecosystems, and the assumed equivalence of natural forests and plantations in terms of ecological processes and functions must be critically re-examined.

Materials and methods

Forests of study sites. This study was conducted in the Coastal Range of El Maule region (35 $\mathrm{S}$ ), Cauquenes province, central Chile, which is presently covered by a novel landscape matrix dominated by pine plantations, with relatively small remnant fragments of the original native forest (less than 700 ha, all together), often restricted to steep hills and deep ravines on the Coastal Range. Forestry plantations in this region cover more than 600,000 ha, mostly represented by Pinus radiata trees, versus 400,000 ha of native forest, $>95 \%$ of it confined to 


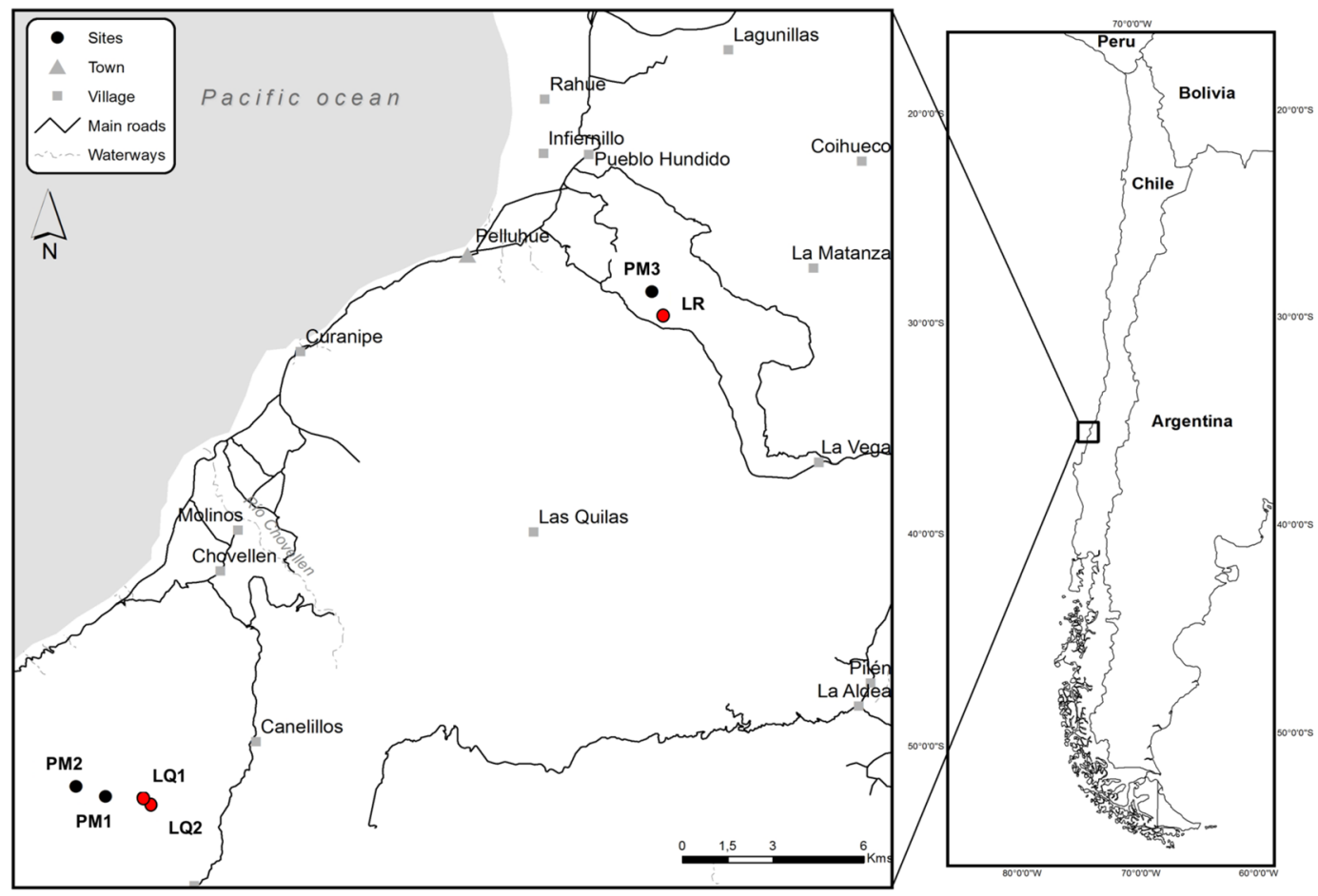

Figure 1. Sampling sites in Cauquenes province, El Maule Region, $35^{\circ} \mathrm{S}$, in central Chile. Red dots are native forest sites (LQ1: Los Queules 1, LQ2: Los Queules 2, LR: Los Ruiles) and black dots are pine plantation sites (PM1: Pine Monoculture 1, PM2: Pine Monoculture 2, PM3: Pine Monoculture 3).

the Andes range ${ }^{36}$. A Mediterranean-type climate prevails over the entire study area, with rainfall concentrated during the winter months, May to August, followed by hot and dry summers ${ }^{37}$ extending from November to April. The Coastal Range is defined by a common basement of metamorphic rock of Palaeozoic age, with some intrusive volcanic rocks. Superimposed to this basement, younger rocks and volcanic materials of Quaternary or Tertiary age transported from the Andes, can be found ${ }^{38}$. The original native forests, named Maulino forest, have a canopy dominated by a mixture of deciduous and evergreen tree species, including Nothofagus glauca (Nothofagaceae), Persea lingue (Lauraceae) and Gevuina avellana (Proteaceae), and less frequently N. obliqua, Cryptocarya alba (Lauraceae), and Aristotelia chilensis (Elaeocarpaceae) in some patches ${ }^{39,40}$. In addition, few remnant forest patches harbour narrowly distributed and locally endangered tree species, such as N. alessandri, Pitavia punctata (Rutaceae), and Gomortega keule (Gomortegaceae), all of them endemic to the Coastal Range of the study area $^{41}$. The remaining native forests have survived a long history of human impacts, including degradation by logging and fire over the $20^{\text {th }}$ century, probably leading to the loss of plant species from forest fragments. Areas presently covered by pine plantations have been largely derived from fire disturbance to native forests and abandoned croplands. Nowadays, there are only two main Maulino forest remnants, both of which have been added to the Chilean National System of Protected Areas in the 1990s. These are Los Queules, with $417 \mathrm{ha}$ of second-growth mixed evergreen-deciduous forest, and Los Ruiles with a total of 64 ha of predominantly deciduous forest $^{38}$.

Sampling sites. Three sites covered by secondary native forest were selected for comparison with young forestry plantations, all of them were located within two protected areas, one site was located in Los Ruiles National Reserve ( $\left.35^{\circ} 35^{\prime} 57^{\prime \prime} \mathrm{S} ; 72^{\circ} 21^{\prime} 06^{\prime \prime} \mathrm{W}\right)$ and two sites in Los Queules National Reserve ( $\left.35^{\circ} 59^{\prime} 19^{\prime \prime} \mathrm{S} ; 72^{\circ} 41^{\prime} 15^{\prime \prime} \mathrm{W}\right)$. Los Ruiles is a relatively small area of secondary and riparian forest ( $45 \mathrm{ha})$ dominated by winter-deciduous trees on steep hills and evergreen broad-leaved trees near the ravine. Los Queules is part of a larger fragment (600 ha) with a closed canopy of broad-leaved, evergreen forest. All three sites (Fig. 1) were selected considering a minimum distance of $50 \mathrm{~m}$ from any edge of native forest ${ }^{42}$, predominantly in areas with gentle slopes $\left(<30^{\circ}\right)$. For the comparisons, we selected three sites with similar topography, in gentle-sloped $P$. radiata plantations, less than $5 \mathrm{~km}$ from the nearest native forest site (Fig. 1). Sampling was also conducted at least $50 \mathrm{~m}$ away from patch edges. Plantations in the zone were 10-15 years old, with an average stem diameter at breast height of $26.3 \pm 3.3 \mathrm{~cm}$, with presence of an established understory of native and exotic shrubs derived from sprouting or post-disturbance colonization (Supplementary Fig. S1).

Soil sampling. Three replicate plots were sampled at each of the pine plantation and native forest sites, and sampling was repeated 4 times over the course of one year to account for seasonal variation in soil invertebrate communities and properties, for a total of 72 sampling plots. New plots were established in each sampling event to avoid resampling of previously disturbed soil. Plots where distributed as follows in both native forest and pine 
plantation sites: We set up a 30-m long transect, following a north-south direction and at 15, 30 and $45 \mathrm{~m}$ from the start of the transect, we rolled two dice to determine the number of steps away from the transect where each plot would be located. We setup three $10 \times 10 \mathrm{~m}$ plots where all canopy and understorey woody plants were identified to species, and their relative cover was estimated visually and assigned to five cover categories $(0-10 \%, 11-20 \%$, $21-50 \%, 51-75 \%, 76-100 \%)^{43}$. Subsequently, within each plot, we randomly selected three sampling points from where soil cores $(10 \mathrm{~cm}$ diameter, $15 \mathrm{~cm}$ long) were extracted to collect the soil biota. In these same points, we estimated water infiltration by measuring the time that a defined volume of water took to infiltrate a constant soil area using the formula: Infiltration $\left(\mathrm{cmh}^{-1}\right)=\mathrm{Q} / \mathrm{AxT}$, where "Q" is the quantity of water $\left(250 \mathrm{~cm}^{3}\right)$, "A" the sampled area $\left(78.5 \mathrm{~cm}^{2}\right)$, and " $T$ " the time (hours) $)^{44}$. From the same points, we also extracted soil cores $(10 \mathrm{~cm}$ depth) for assessing total carbon and total nitrogen using dry combustion (Carlo-Erba Elemental Analysis). Soil pH was measured with ExStik pH Meter Extech PH100, and instantaneous soil water content was estimated by the gravimetric method.

Soil cores collected from each plot were stored at $5{ }^{\circ} \mathrm{C}$ in closed plastic bags prior to taking them to the laboratory. Soils were sieved and placed for three consecutive days in Berlese funnels for extraction of soil invertebrates $^{45}$. After three days in the Berlese funnels, all soil remaining was manually examined under a $3 \times$ magnifying scope to collect any remaining individuals. Most groups of soil invertebrates were identified to the order level, except for better known groups, such as Coleoptera, when identifications of families was possible using available keys $^{46-55}$.

Data analyses. Because within-site seasonal variation was small compared to between-site variation, data from all sampling events were pooled, resulting in 12 replicate plots at each site. Sampling points within each plot are taken as pseudo-replicates for soil and invertebrate data.

The full dataset collected consisted in 216 sampling points across 72 plots, distributed in two systems: Pine plantation and native forest, with 36 plots in each (see sampling scheme in Supplementary Fig. S2). Differences in understorey plant cover and soil properties $(\mathrm{pH}$, total carbon, total nitrogen, gravimetric water content, and water infiltration) among sites representing native forest and plantations, were tested using Linear Mixed Models (nlme package in R) with system as fixed effect and sites, plots and samples as nested random effects. Further, we performed permutation multivariate analysis of variance (PERMANOVA) to explore the overall difference in soil properties between pine plantation and native forest sites. Also, we performed a Principal Component Analysis to estimate which soil properties explained more variance among forest systems.

Invertebrate diversity in soil samples from pine plantations and native forest sites was estimated using Shannon's diversity index $\left(H^{\prime}\right)$, and $H^{\prime}$ was calculated as: $H^{\prime}=-\sum\left(\mathrm{p}_{\mathrm{i}}{ }^{*} \ln \left(\mathrm{p}_{\mathrm{i}}\right)\right)$, where " $H$ " is the diversity index and " $\mathrm{p}$ " is the proportion of species i relative to the total number of species in the sample. Comparisons between native forest and pine plantation Shannon's diversity index were made with one-way ANOVA. Invertebrates abundance comparisons between pine plantation and native forest were made using a Generalized Linear Mixed Models with Poisson distribution.

To examine understorey plant cover and soil invertebrate diversity in all sampled sites, we used Fisher's Alpha diversity index ${ }^{56}$; the relationship between soil invertebrate diversity and soil properties was tested with Linear Mixed Effects Models, with soil properties and system as fixed effects, while sites and plots as random effects.

Additionally, we computed sample-based rarefaction curves with $95 \%$ confidence intervals ${ }^{57}$ to compare differences in the number of invertebrate taxa (at the order level) among soil samples from native forests and pine plantation sites. Rarefaction curves compare the total number of individuals counted with repeated random sampling to the total number of taxa found in soil ${ }^{58}$, as it produces an accumulation curve that reaches a plateau when most of the taxa expected for the site are sampled. Accordingly, we computed the total species richness estimator $\mathrm{Chao}^{57}$, and to integrate both abiotic and biotic information for native forests and pine plantations, we computed a non-metric multidimensional scaling (NMDS) and the statistical analysis of similarities (ANOSIM) with Chao distance. All analyses were performed in R v.3.2.0 $0^{59}$.

\section{Results}

Soil invertebrate communities. Rarefaction curves showed that the accumulation of invertebrate taxa (identified at the order level) in soil samples reached different plateau levels in native forest and pine plantations (Fig. 2A). The asymptote indicated that sampling efforts were sufficient to characterize the local soil fauna of both systems (native forest and pine plantation). The total number of orders present, estimated by the index Chaol, was lower in soil samples from pine plantations than in soil samples from native forest sites $(22 \pm 2.580$ and $27 \pm$ 0.735 orders, respectively, $\mathrm{N}=36$ each). Similarly, Shannon's diversity index based on soil invertebrate taxa was significantly lower in all pine plantation sites that in native forest sites (Fig. 2B).

We found a total of 27 orders of invertebrates in the 216 soil samples from all native forest and pine plantations sites. All the 27 orders of soil invertebrates were present in soils from native forest, while only 22 orders were found in pine plantations. Five invertebrate orders were exclusively found in native forest sites: Opilionida, Neuroptera, Trichoptera, Onycophora and Anoplura.

Soil properties and understorey cover. Variables such as understorey plant cover, water infiltration rates and total soil carbon content differed significantly between soil samples from native forests and pine plantations (Table 2). Soils under pine plantations $(\mathrm{N}=36)$ tended more acidic and considerably drier than soils under native forest cover in the same study period.

Overall, understorey plant cover was significantly lower in young pine plantations than in native forests $(25 \%$ versus $50 \%, \mathrm{p}<0.05, \mathrm{~N}=72$ ). Water infiltration and soil water content at the time of sampling were both significantly lower in pine plantation sites, with water infiltration rates ten times lower than in native forest sites. Soil water content was nearly $10 \%$ lower in pine plantation sites than in native forest sites, and soil $\mathrm{pH}$ was lower 
A

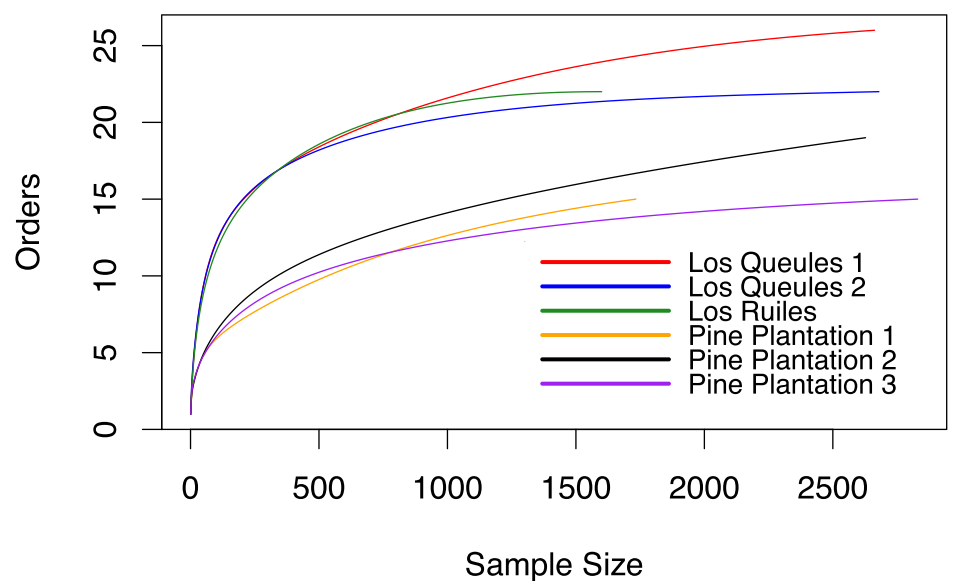

B

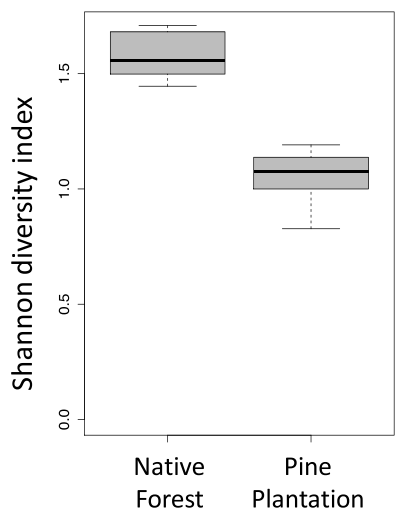

Figure 2. (A) Rarefaction analysis of the total number of invertebrate orders as a function of the total number of individuals collected from soil cores in three native forest sites and three pine plantation sites. (B) Shannon's diversity index for native forest and pine plantation sites, $\mathrm{F}_{1,70}=67.62, \mathrm{P}<0.001, \mathrm{~N}=72$.

\begin{tabular}{|l|c|l|l|l|l|}
\hline Soil Property & Estimate & Standard Error & DF & t-value & p-value \\
\hline Total C & -11.35 & 3.09 & 4 & -3.67 & $\mathbf{0 . 0 2 1}$ \\
\hline Total N & -0.48 & 0.19 & 4 & -2.51 & 0.065 \\
\hline $\mathrm{pH}$ & -0.11 & 0.05 & 4 & -2.23 & 0.089 \\
\hline Moisture & 7.86 & 1.08 & 4 & -2.18 & 0.094 \\
\hline Infiltration & -16.80 & 4.17 & 4 & -4.03 & $\mathbf{0 . 0 1 6}$ \\
\hline Understorey & -33.89 & 4.88 & 4 & -6.94 & $\mathbf{0 . 0 0 2}$ \\
\hline
\end{tabular}

Table 2. Linear Mixed Models of soil properties between native forest and pine plantation sites, with random effects of sites and plots. Bold font represents significant code of $\mathrm{p}<0.05$.

\begin{tabular}{|l|l|l|}
\hline \multicolumn{4}{|l|}{ Permutation N: 9999 } & P \\
\hline Factor & $\mathrm{F}$ & $\mathbf{P}$ \\
\hline System & $\mathrm{F}_{1,66}=75.70$ & $<\mathbf{0 . 0 0 1}$ \\
\hline Site & $\mathrm{F}_{2,66}=3.77$ & $<\mathbf{0 . 0 5}$ \\
\hline Interaction & $\mathrm{F}_{2,66}=14.46$ & $<\mathbf{0 . 0 0 1}$ \\
\hline
\end{tabular}

Table 3. PERMANOVA for soil properties of native forest and pine plantation with three sites (replicates) each.

(therefore soil was more acid) and less variable in pine plantations, although the difference was not statistically significant. Finally, pine plantations soils had less than one half of the total carbon and total nitrogen found in soils from native forest sites, these differences were significant for C but not for N (Supplementary Fig. S3). Overall, soil properties analysed with PERMANOVA showed significant differences between native forest and pine plantations, because of differences among sites (Table 3). Principal components analysis (PCA) showed similar trends, where understorey plant cover, soil water infiltration and soil water content accounted for $92 \%$ of the variance between pine plantation and native forest sites (Supplementary Fig. S4).

Biotic and abiotic controls on soil invertebrate communities. Understorey plant cover in both native forest and pine plantation plots, was positively related with soil invertebrate community diversity at the plot level (Fig. 3A), documenting the strong dependence of belowground diversity on above-ground plant diversity. Moreover, the overall proportion of plant cover in the understorey was also significantly lower in plantations than in native forest plots (30\% versus 50\%, respectively, Supplementary Fig. S3). In addition, soil invertebrate diversity (estimated at the order level) was strongly related to soil water content on each plot (Fig. 3B). This result supports a functional relationship between soil invertebrate assemblages and soil water availability, as we show that soils of pine plantations, which have a lower soil invertebrate diversity, had significantly lower moisture content than soils under native forest cover.

Taxonomic and functional differences between soil invertebrate communities. Soil community composition, in terms of invertebrate orders, differed greatly between native forest and pine plantation sites (Fig. 4). Rare invertebrate taxa in native forests, defined as taxa with less than five individuals on average per 

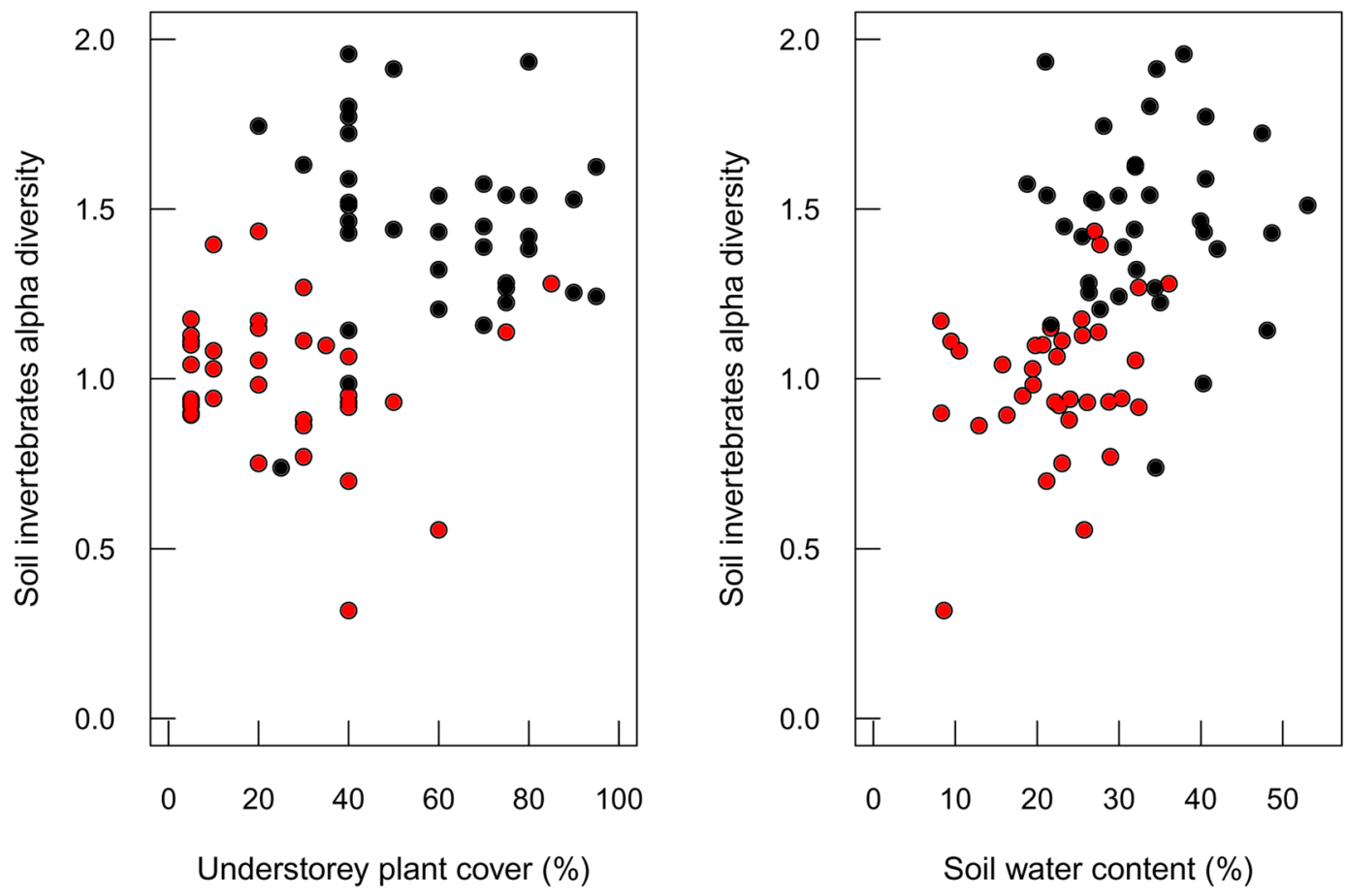

Figure 3. Relationship between soil invertebrates' alpha diversity index and A) understorey plant cover $(\%)(\mathrm{SE}=0.01, \mathrm{DF}=64, \mathrm{t}$-value $=2.75, \mathrm{p}<0.001)$ and $\mathrm{B})$ soil water content $(\%)(\mathrm{SE}=0.02, \mathrm{DF}=64$, $\mathrm{t}$-value $=-2.19, \mathrm{p}<0.05)$. Black dots are native forest plots, and red dots are pine plantation plots.

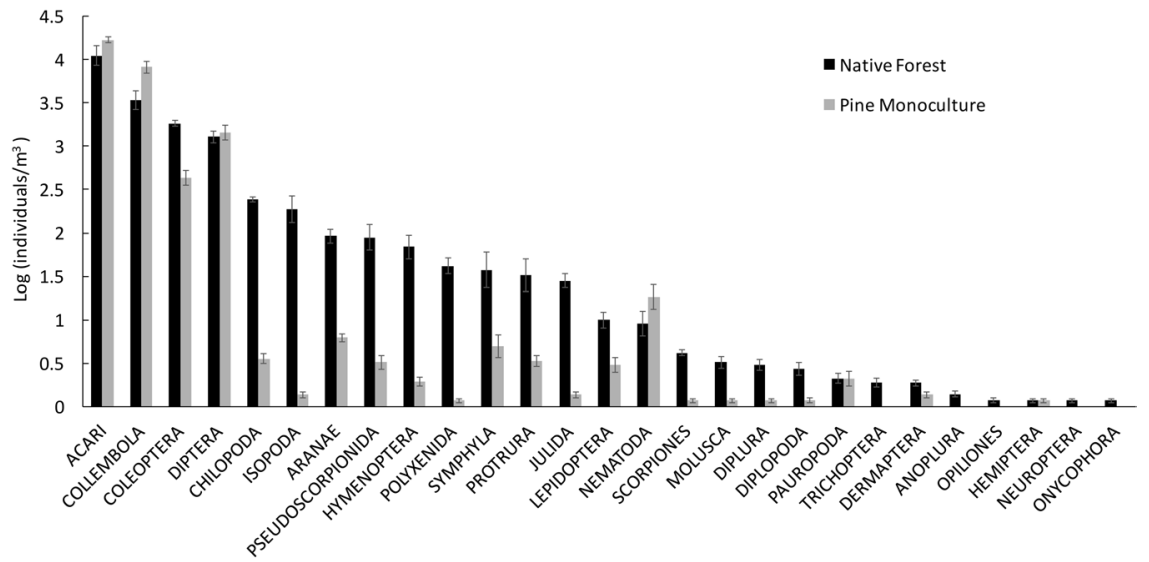

Figure 4. Average abundance of soil invertebrate orders found in native forest sites (black bars) and pine plantation sites (grey bars). Vertical lines indicate standard errors. Invertebrate orders are ranked according to their decreasing abundance in native forest sites. Abundances are in logarithmic scale.

sample (i.e. Anoplura, Neuropteran, Onycophora, Trichoptera and Opilionida), were completely absent from pine plantation sites. On the other hand, widespread groups such as Collembola, Diptera and Nematoda were more abundant in soils under pine plantations than in native forest. Top predator groups (i.e. Chilopoda, Aranae, Scorpiones, Pseudoscorpionida and Staphylinidae) were significantly less abundant and had lower diversity in pine plantation than in forest sites (Fig. 5). GLM of the abundances of each group showed significant differences between pine plantation and native forest systems for all invertebrate orders but Acari (Supplementary Fig. S6).

\section{Discussion}

Consistent differences in soil properties were observed between native forests from central Chile and pine plantation sites in the same region, over similar geological substrates and under the same climate. These differences in soils properties associated with forest cover type (native forest versus pine plantations) were in turn related to marked differences in underground invertebrate assemblages. With respect to the soil physico-chemical status and the characteristics of the soil biota, both differentiated clearly between the two ecological systems compared: native forest and pine plantations. Native forest soil was less compacted, and, despite low sample size, appears 


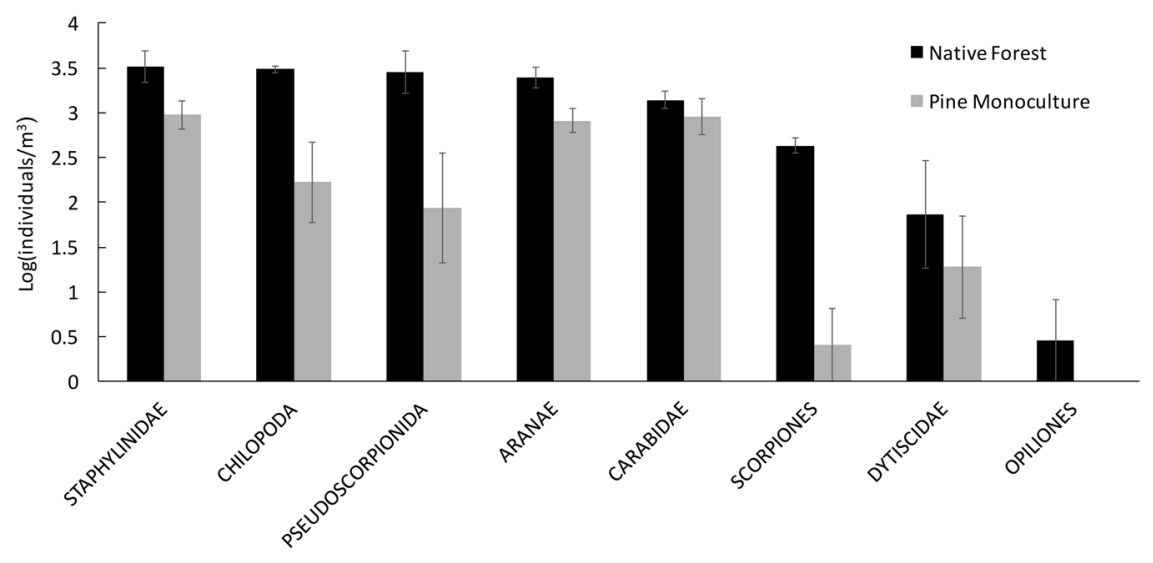

Figure 5. Average abundance of invertebrate predators found in soils of native forest sites (black bars) and pine plantation sites (grey bars). Vertical lines indicate standard errors. Taxa are ranked according to their decreasing abundance in native forest sites. GLM of the abundances of each group showed significant differences between pine plantation and native forest systems for Aranae $(\mathrm{p}<0.05)$, Staphylinidae $(\mathrm{p}<0.5)$, Chilopoda $(\mathrm{p}<0.1)$ and Pseudoscorpionida $(\mathrm{p}<0.001)$.

to be less acidic, and had higher water contents than soil under pine plantation. More importantly, native forest soil was consistently richer in carbon (total C) than soils from pine plantation sites. Differences among sites were evident despite the similarities in climate, substrates and past disturbance history across the landscape mosaic under study, and especially considering the short distances $(<5 \mathrm{~km})$ separating sampling sites under pine cover and under native forest cover. Differences in soil structure and above-ground plant communities were strongly related to contrasting diversity and composition of invertebrate assemblages. According to our analysis, lower invertebrate diversity in pine plantation sites was consistently associated with soil properties that might be promoting the loss of soil fauna (biotic homogenization). Although it is difficult to ascertain the causal relationships for the observed changes in soil invertebrate community composition and associated soil properties, the current management of pine plantations (including short rotation times and burning of the residual biomass after harvest) and the low diversity of the canopy composition (only one tree species in plantations) can drive changes in invertebrate diversity and the ecological processes that sustain it (discussed below).

Soil properties, ecosystem processes, and above-belowground functional links. Soil properties reported here can be considered environmental proxies of soil structure and ecosystem functions that are relevant for the long-term sustainability of ecosystem productivity ${ }^{15}$. Water infiltration rate is an indicator of soil compaction and aeration, and water content indicates the capacity of soils to retain water in the strongly seasonal environment of central Chile, under a Mediterranean-type climate with water supply concentrated between May and August ${ }^{37}$. In this context, our data supports recent assessments of the indirect effects of extensive forestry plantations on water availability in similar bio-climatic locations ${ }^{34,60,61}$. When compared to areas dominated by native vegetation, massive forestry plantations are characterized by lower water retention, affecting its supply and quality for other downslope land uses. At the same time, the management of plantations with short rotation periods (15-25 years) are related to greater nutrient losses to stream water via sediments ${ }^{34}$. The impact of plantations on water storage and provision is one of the most valued and, at the same time, the most altered of all ecosystem benefits that forests in this region provide to local communities ${ }^{21}$.

Previous studies have reported strong soil acidification and nutrient depletion under pine plantations ${ }^{22,31,33,62,63}$; however, despite the rapid regional growth of forestry plantations, these effects have not been assessed in Chile before. Lower soil $\mathrm{pH}$ under pines has been attributed to the redistribution of mineral exchangeable cations from soil to fast-growing tree biomass; cations tend to be depleted from soil exchange sites and replaced by $\mathrm{H}^{+}$, thereby turning soils increasingly acid $^{33}$. Considering that humid forest soils tend to be more acidic than other ecosystems due to increased production of carbonic acid from higher rates of autotrophic respiration ${ }^{64}$, the greater acidification of pine plantation soils may represent a problem for the soil biota ${ }^{33}$. Furthermore, soil acidification could have detrimental effects on soil fertility, also modifying soil faunal communities ${ }^{65,66}$ because invertebrate taxa show different $\mathrm{pH}$ preferences ${ }^{67-69}$. For example, collembolans tend to increase under greater soil acidity, which can be explained by their physiological tolerance to acid soils ${ }^{65}$. Accordingly, we found that, unlike most other invertebrate orders collected, collembolans and nematodes were almost twice more abundant in sites under pine plantations.

Studies of exotic plantations in other Mediterranean-climate regions have documented similar differences in entomofaunal diversity with respect to native forest remnants ${ }^{70-73}$. Authors have highlighted the importance of maintaining an understorey of native plant species for the conservation of invertebrate communities ${ }^{74}$; however, the present study shows that, in all the sites sampled, both plant species richness and cover in the understorey were significantly lower in plantations sites than in native forest plots. This difference is presumably the result of higher tree densities and stronger shading under plantations, as well as the collateral effects of harvesting operation after short rotations. Maintaining understorey cover, therefore, may require planned efforts to sustain 
this layer of vegetation in plantations. Such management may be at odds with the need to prevent wildfire and facilitating the harvest operation. The reduced habitat heterogeneity and lower litter diversity, characteristic of plantations, offers less shelter and lower nourishment opportunities to soil invertebrates, which could lead to a rapid biotic homogenization of soil communities. The less common groups of invertebrate taxa ("rare" taxa in Fig. 4), which were only found in native forest sites, such as Trichoptera, Anoplura, Hemiptera, Neuroptera and Onycophora, were conspicuously absent from pine plantation sites. On the other hand, the most common and widely distributed invertebrate groups (i.e., Acari, Collembola and Diptera) were more abundant in pine plantations than in native forest. The replacement of rare species by widespread ones is a known feature of the biotic homogenization process ${ }^{9,10}$.

Some soil invertebrates are at the top of trophic food chain, and therefore their abundances may reflect the integration of a range of underground processes ${ }^{75}$. In this work, top predators (i.e. Aranae, Chilopoda, Scopiones, Pseudoscorpionida and Staphilinidae) were at least twice times more abundant in native forest soils than in soils under pine plantations. Top predator abundance may be an indicator of ecosystem productivity, as energy constraints the abundance and diversity of top predators, with more productive ecosystems sustaining larger and more diverse trophic chains ${ }^{76,77}$. Moreover, total soil carbon content, which is often used as indicator of overall soil fertility ${ }^{33}$, was significantly lower in pine plantation sites, supporting the hypothesis that pine soils become less productive than native forest soils, a condition that could be a consequence of greater nutrient uptake by the fast-growing trees of $P$. radiata. Even though further analysis is needed to identify the specific linkages between the different soil invertebrate groups found in soil and their functional roles in the ecosystem, we propose here that invertebrate communities can be useful indicators of soil nutrient status because of their prominent place in the community of soil organisms and their key function in promoting soil fertility and environmental heterogeneity ${ }^{5,75}$.

Finally, it is important to state that even though the invertebrate community identification was very coarse (just to the level of order), a finer identification of taxa would have accentuated the differences among forest systems. Functional roles and trophic positions can be quite diverse within some orders (e.g. Acari), and the coarseness of our data fails to capture within-order differences between systems. This limitation in our study is important, but it was due to the lack of natural history information about inconspicuous groups such as soil micro-invertebrates in southern South America, and because most of the individuals sampled were at larval stages, making identification yet more difficult.

Soil invertebrate communities as indicators of ecosystem status. Differences among sites across the forested landscape were less important for soil properties and invertebrate community composition than differences in canopy cover between native forest and pine plantation stands. This result reinforces the idea that exotic tree plantations are functionally different from floristically diverse native forests. NMDS ordination (Supplementary Fig. S4) suggests that differences in soil invertebrate communities could be explained at least partly by contrasting soil properties, such as soil nutrient contents and water infiltration rates, thus revealing a functional linkage between soil biodiversity and ecosystem processes.

If a continuum of degradation stages occurs from a "healthy forest ecosystem" to a "severely degraded forest", the threshold for a regime shift from a healthy condition to a degraded condition ${ }^{78}$ will not depend solely on the conservation of a single remnant forest area, but also on its interactions with the surrounding landscape matrix including all other land uses. Accordingly, to ensure the maintenance of healthy ecosystems within the landscape mosaic dominated by pine plantations in central Chile, requires a better understanding of key functional connections among ecosystems, such as the continuity of underground soil processes that sustain aboveground productivity.

The present work makes a relevant contribution to resolve an important ecological question, regarding what makes a forest a forest ${ }^{79}$, or what makes a remnant native forest under conservation different from a managed tree plantation. This question is not only of theoretical relevance because many forestry companies and some international organizations often make no distinction between "native forest" cover and "plantation forest" cover. From the evidence discussed here, the answer to this question goes beyond the similarity in the remote perception of different cover types. We must be able to distinguish the nature of the complex system locally defined by vertical layering, above and belowground linkages, and functional biodiversity, all of which are the product of species identities, biogeochemical process, ecosystem functions, and history of land cover change $\mathrm{e}^{79-81}$. The challenge for plantation managers is to design a production system that can be suitable for preserving both biotic diversity and ecosystem processes. In this context, we propose that soil health must be a critical aspect of the assessment of forestry systems and suggest that the composition and trophic structure of the soil biota can be a measure of such health.

Tree plantations as carbon sinks and biodiversity reservoirs. Timber plantations are often considered as contributors to the mitigation of climate change, under the argument that the plantation of deforested areas (often termed reclamation) with fast-growing trees should enhance carbon capture. In fact, global tree cover is often quantified as a suitable indicator of the capacity of vegetation on land to act as carbon sink for climate warming mitigation ${ }^{82}$. Along the same line of reasoning, tree plantations may be considered as biodiversity reservoirs $^{70}$, supporting the idea that a functional replacement of native forests by tree plantations can still provide suitable habitat for native biodiversity ${ }^{12}$. We argue here that there are two important caveats: first, many plantations are being placed on fertile sites that were previously forested, and secondly, native forests have been generally shown to store much more carbon, distributed in epiphytes, understory plant cover, litter and soil ${ }^{21}$, and this carbon remains in the ecosystem for longer periods than in tree plantations. Woody debris in native forests also provide a greater diversity of habitats for local animal communities (e.g., fallen logs and standing dead trees ${ }^{83,84}$ ). Recently, Naudts ${ }^{84}$ reported increased carbon emissions from young forestry plantations in Europe after 50 years 
of forest management, thus questioning the functional role of tree plantations as effective carbon sinks, as often argued. In this work, we show that pine plantations in central Chile are not a reservoir for underground biodiversity, originally present in native forest communities. Consequently, we propose that the massive and rapid expansion of plantations, even though canopy cover at the landscape scale may remain the same, it does not mean that one forest system is being replaced by an analogous one, because many ecological functions such as those provided underground by soil processes, yet hard to perceive by the human eye, are being significantly changed ${ }^{85}$.

\section{Conclusion}

Results of the present study document that there is considerable loss of understorey plant cover, soil invertebrate diversity, and nutrients when replacing diverse native forests by single-species, exotic plantations at a massive scale. The loss of inconspicuous biodiversity from native forest ecosystems represents a significant component of the process of biotic homogenization. In this study, we show that depauperated soil communities become predominant in the short lapse that $P$. radiata plantations have been in place in the study sites (less than 40 years). Equally concerning are changes in critical ecosystem services, such as nutrient cycling, soil structure, and carbon and water storage ${ }^{86}$. We hope that these findings will encourage government agencies and forestry companies to critically re-examine policies that promote the rapid increase in cover of single-species plantations at the regional scale, therefore preventing serious impacts of management on belowground processes that sustain diversity and productivity.

Received: 20 March 2019; Accepted: 8 April 2020;

Published online: 08 May 2020

\section{References}

1. Sala, O. E. et al. Global biodiversity scenarios for the year 2100. Science. 287, 1770-1774 (2000).

2. Pereira, H. M. et al. Scenarios for Global Biodiversity in the 21st Century. Science. 330, 1496-1501 (2010).

3. Miranda, A., Altamirano, A., Cayuela, L., Pincheira, F. \& Lara, A. Different times, same story: Native forest loss and landscape homogenization in three physiographical areas of south-central of Chile. Applied Geography. 60, 20-28 (2015).

4. FAO. Global Forest Resources Assessment 2015: How are the world's forests changing? (Food and Agriculture Organization of the United Nations, 2015).

5. Franco, A. L. et al. Loss of soil (macro) fauna due to the expansion of Brazilian sugarcane acreage. Science of the Total Environment. 563, 160-168 (2016).

6. Mead, D. J. Sustainable management of Pinus radiata plantations. (Food and Agriculture Organization of the United Nations, 2013).

7. Chapin, F. S. et al. Consequences of changing biodiversity. Nature. 405, 234-242 (2000).

8. Ibarra, J. T. \& Martin, K. Biotic homogenization: loss of avian functional richness and habitat specialists in disturbed Andean temperate forests. Biological Conservation. 192, 418-427 (2015).

9. Mori, A. S. et al. Biotic homogenization and differentiation of soil faunal communities in the production forest landscape: taxonomic and functional perspectives. Oecologia. 177, 533-544 (2015).

10. Olden, J. D. \& Rooney, T. P. On defining and quantifying biotic homogenization. Global Ecology and Biogeography. 15, 113-120 (2006).

11. Hobbs, R. J., Higgs, E. S. \& Hall, C. (eds.) Novel ecosystems: intervening in the new ecological world order (John Wiley \& Sons, 2013).

12. Espinosa, M., Acuna, E., Cancino, J., Munoz, F. \& Perry, D. A. Carbon sink potential of radiata pine plantations in Chile. Forestry. 78, $11-19$ (2005).

13. INFOR. Anuario Forestal 2016, Chilean Statistical Yearbook of Forestry. 1-154 (2016).

14. Wright, J. P. \& Jones, C. G. Predicting effects of ecosystem engineers on patch-scale species richness from primary productivity. Ecology. 85, 2071-2081 (2004)

15. Bardgett, R. D. \& Wardle, D. A. (eds.) Aboveground-belowground linkages: biotic interactions, ecosystem processes and global change. (Oxford University Press, 2010).

16. Crisp, P. N., Dickinson, K. J. M. \& Gibbs, G. W. Does native invertebrate diversity reflect native plant diversity? A case study from New Zealand and implications for conservation. Biological Conservation. 83, 209-220 (1998).

17. Siemann, E., Tilman, D., Haarstad, J. \& Ritchie, M. Experimental tests of the dependence of arthropod diversity on plant diversity. American Naturalist. 152, 738-750 (1998).

18. De Deyn, G. B., Raaijmakers, C. E., Zoomer, H. R. \& Berg, M. P. Soil invertebrate fauna enhances grassland succession and diversity. Nature. 422, 711 (2003)

19. Aerts, R. Climate, leaf litter chemistry and leaf litter decomposition in terrestrial ecosystems: a triangular relationship. Oikos. 79, 439-449 (1997)

20. Cornelissen, J. H. et al. Leaf structure and defence control litter decomposition rate across species and life forms in regional floras on two continents. The New Phytologist. 143, 191-200 (1999).

21. Bonan, G. B. Forests and climate change: Forcings, feedbacks, and the climate benefits of forests. Science. 320, 1444-1449 (2008).

22. Chirino, I., Condron, L. M., McLenaghen, R. D. \& Davis, M. Effects of plantation forest species on soil properties in Soil Solutions for a Changing World: Proceedings of the 19th World Congress of Soil Science (eds. Gilkes, R. \& Prakongkep, N.) 1-6 (Brisbane, Australia ed., 2010).

23. Díaz, S. et al. Summary for policymakers of the global assessment report on biodiversity and ecosystem services of the Intergovernmental Science-Policy Platform on Biodiversity and Ecosystem Services. (IPBES secretariat, 2019).

24. Lavelle, P. et al. Soil function in a changing world: the role of invertebrate ecosystem engineers. European Journal of Soil Biology. 33, 159-193 (1997).

25. Heneghan, L., Coleman, D. C., Zou, X., Crossley, D. A. \& Haines, B. L. Soil microarthropod contributions to decomposition dynamics: Tropical-temperate comparisons of a single substrate. Ecology. 80, 1873-1882 (1999).

26. Echeverría, C. et al. Rapid deforestation and fragmentation of Chilean temperate forests. Biological conservation. 130, 481-494 (2006).

27. Lavelle, P. et al. Soil invertebrates and ecosystem services. European journal of soil biology. 42, 3-15 (2006).

28. Lal, R. Soil carbon sequestration impacts on global climate change and food security. Science. 304, 1623-1627 (2004).

29. Singh, S., Davey, S. \& Cole, M. Implications of climate change for forests, vegetation and carbon in Australia. New Zealand. Journal of Forestry Science. 40, 141-152 (2010).

30. Cruz, M., de Mar, P. \& Adshead, D. Radiata pine plantation fuel and fire behaviour guide. GHD, www.ghd.com/PDF/ PinusRadiataFuelandFireGuide.pdf (2011). 
31. Turner, J. \& Lambert, M. J. Soil properties as affected by Pinus radiata plantations. New Zealand. Journal of Forestry Science. 18, 77-91 (1988)

32. Chapela, I. H., Osher, L. J., Horton, T. R. \& Henn, M. R. Ectomycorrhizal fungi introduced with exotic pine plantations induce soil carbon depletion. Soil Biology \&. Biochemistry. 33, 1733-1740 (2001).

33. Berthrong, S. T., Jobbàgy, E. G. \& Jackson, R. B. A global meta-analysis of soil exchangeable cations, pH, carbon, and nitrogen with afforestation. Ecological Applications. 19, 2228-2241 (2009).

34. Oyarzún, C. E., Frêne, C., Lacrampe, G., Huber, A. \& Hervé, P. Propiedades hidrológicas del suelo y exportación de sedimentos en dos microcuencas de la Cordillera de la Costa en el sur de Chile con diferente cobertura vegetal. Bosque. 32, 10-19 (2011).

35. Hess, L. J. T. \& Austin, A. T. Pine afforestation alters rhizosphere effects and soil nutrient turnover across a precipitation gradient in Patagonia, Argentina. Plant and Soil. 415, 449-464 (2017).

36. Quiroz, I. et al. Evaluación y análisis de los métodos de regeneración aplicados en el tipo forestal roble-raulí-coigüe de la precordillera de los Andes de las regiones del Bío Bío y la Araucanía. Bosque Nativo. INFOR-MINAGRI. (2011).

37. Armesto, J. J. et al. Conifer forests of the Chilean coastal range in Ecology of the Southern Conifers (eds. Enright, N. J. \& Hill, R. S.) 156-170 (Melbourne University Press, 1995).

38. Smith-Ramírez, C. The Chilean coastal range: a vanishing center of biodiversity and endemism in South American temperate rainforests. Biodiversity \& Conservation. 13, 373-393 (2004).

39. San Martín, J. \& Donoso, C. Floristic structure and human impact on the Maulino forest of Chile in Ecología de los bosques nativos de Chile (eds. Armesto, J. J., Villagrán, C \& Arroyo, M. K.) 153-167 (Editorial Universitaria, 1995).

40. Bustamante, R. O., Simonetti, J. A., Grez, A. A. \& San Martín, J. Fragmentación y dinámica de regeneración del bosque maulino: diagnóstico actual y perspectivas futuras in Historia, biodiversidad y ecología de los bosques costeros de Chile (eds. Smith-Ramírez, C., Armesto J. J. \& Valdovinos, C.) 555-564 (Editorial Universitaria, 2005).

41. San Martín, J. Floristic and vegetative structure of the Nothofagus alpina (Fagaceae) remanent forest of the Coastal Range, central Chile. Bosque. 24, 71-85 (2003).

42. Magura, T. Carabids and forest edge: spatial pattern and edge effect. Forest Ecology and Management. 157, 23-37 (2002).

43. Van der Maarel, E. Transformation of cover-abundance values for appropriate numerical treatment-Alternatives to the proposals by Podani. Journal of Vegetation Science. 18, 767-770 (2007).

44. Franzluebbers, A. J. Water infiltration and soil structure related to organic matter and its stratification with depth. Soil \& Tillage Research. 66, 197-205 (2002).

45. Basset, Y., Hammond, P. M., Barrios, H., Holloway, J. D. \& Miller, S. E. Vertical stratification of arthropod assemblages in Arthropods of tropical forests (eds. Basset, I., Novotny, V., Miller, S. \& Kitching, R.) 17-27 (Cambridge University Press, 2003).

46. Martínez, R. I. \& Casanueva, M. E. Comparación cuali-cuantitativa de la fauna oribatológica de suelo (Acari y Oribatida) de bosques nativos y Pinus radiata. Revista Chilena de Entomología. 22, 25-34 (1995).

47. Borkent, A. \& Wirth, W. W. World species of biting midges (Diptera: Ceratopogonidae). New York: American Museum of Natural History. 1-245 (1997)

48. Rusek, J. Biodiversity of Collembola and their functional role in the ecosystem. Biodiversity and Conservation. 7, 1207-1219 (1998).

49. Covarrubias, R. \& Contreras, A. Variación en los microartrópodos del suelo, por manejos forestales de raleo selectivo y cortes en hoyos de luz. Bosque. 25, 103-116 (2004).

50. Jerez, V. \& Moroni, J. Diversidad de coleópteros acuáticos en Chile. Gayana. 70, 72-81 (2006).

51. Milcu, A., Partsch, S., Langel, R. \& Scheu, S. The response of decomposers (earthworms, springtails and microorganisms) to variations in species and functional group diversity of plants. Oikos. 112, 513-524 (2006).

52. Thyssen, P.J. Keys for identification of immature insects in Current concepts in Forensic entomology. (eds. Amendt, J., Goff, M. L., Campobasso, C. P. \& Grassberger, M.) 25-42 (Springer, 2009).

53. Eisenhauer, N., Sabais, A. C. \& Scheu, S. Collembola species composition and diversity effects on ecosystem functioning vary with plant functional group identity. Soil Biology and Biochemistry. 43, 1697-1704 (2011).

54. Cabrera, G. Manual práctico sobre la macrofauna edáfica como indicador biológico de la calidad del suelo, según resultados en Cuba. Rufford Foundation (RSGF para la Conservación de la Naturaleza, 2014).

55. Covarrubias, R. Comparación de ácaros oribátidos (acarina: oribatida) bajo las mismas especies de plantas de altura, en las cordilleras de los andes y de la costa. Chile central. Revista Chilena de Entomología. 35, 71-82 (2017).

56. Fisher, R. A., Corbet, A. S. \& Williams, C. B. The relation between the number of species and the number of individuals in a random sample of animal population. Journal of Animal Ecology. 12, 42-58 (1943).

57. Colwell, R. K., Mao, C. X. \& Chang, J. Interpolating, extrapolating, and comparing incidence-based species accumulation curves. Ecology. 85, 2717-2727 (2004).

58. Colwell, R. K. \& Coddington, J. A. Estimating terrestrial biodiversity through extrapolation. Philosophical Transactions: Biological Sciences. 345, 101-118 (1994).

59. RCore Team. R: A language and environment for statistical computing. R Foundation for Statistical Computing (2015).

60. Huber, A., Iroume, A. \& Bathurst, J. Effect of Pinus radiata plantations on water balance in Chile. Hydrological Processes. 22, 142-148 (2008).

61. Oyarzún, C. E. \& Herve-Fernandez, P. Ecohidrology and Nutrient Fluxes in Forest Ecosystems of Southern Chile in Biodiversity in ecosystems structure- Linking structure and function (eds. Lo, Y., Blanco, J. \& Roy, S.) 335-352 (Intech, 2015).

62. Brand, D. G., Kehoe, P. \& Connors, M. Coniferous afforestation leads to soil acidification in central ontario. Canadian Journal of Forest Research-Revue Canadienne De Recherche Forestiere. 16, 1389-1391 (1986).

63. Alfredsson, H., Condron, L. M., Clarholm, M. \& Davis, M. R. Changes in soil acidity and organic matter following the establishment of conifers on former grassland in New Zealand. Forest Ecology and Management. 112, 245-252 (1998).

64. Richter, D. D. \& Markewitz, D. How deep is soil? Bioscience. 45, 600-609 (1995).

65. Loranger, G., Bandyopadhyaya, I., Razaka, B. \& Ponge, J. F. Does soil acidity explain altitudinal sequences in collembolan communities? Soil Biology \& Biochemistry. 33, 381-393 (2001).

66. Augusto, L., Ranger, J., Binkley, D. \& Rothe, A. Impact of several common tree species of European temperate forests on soil fertility. Annals of Forest Science. 59, 233-253 (2002).

67. Hyvönen, R. \& Persson, T. Effects of acidification and liming on feeding groups of nematodes in coniferous forest soils. Biology and Fertility of Soils. 9, 205-210 (1990).

68. Van Straalen, N. M. \& Verhoef, H. A. The development of a bioindicator system for soil acidity based on arthropod $\mathrm{pH}$ preferences. Journal of Applied Ecology. 34, 217-232 (1997).

69. Van Straalen, N. M. Evaluation of bioindicator systems derived from soil arthropod communities. Applied Soil Ecology. 9, 429-437 (1998).

70. Estades, C. F. \& Escobar, M. A. Los ecosistemas de las plantaciones de pino de la Cordillera de la Costa in Historia, biodiversidad y ecología de los bosques costeros de Chile (eds. Smith-Ramirez, C., Armesto, J. J. \& Valdovinos, C.) 600-616 (Editorial Universitaria, 2005).

71. Briones, R. \& Jerez, V. Efecto de la edad de la plantación de Pinus radiata en la abundancia de Ceroglossus chilensis (Coleoptera: Carabidae) en la Región del Biobío, Chile. Bosque. 28, 207-214 (2007).

72. Cerda, Y., Grez, A. A. \& Simonetti, J. A. The role of the understory on the abundance, movement and survival of Ceroglossus chilensis in pine plantations: an experimental test. Journal of Insect Conservation. 19, 119-127 (2015). 
73. Fierro, A., Grez, A. A., Vergara, P. M., Ramírez-Hernández, A. \& Micó, E. How does the replacement of native forest by exotic forest plantations affect the diversity, abundance and trophic structure of saproxylic beetle assemblages? Forest Ecology and Management. 405, 246-256 (2017).

74. Grez, A. A., Moreno, P. \& Elgueta, M. Coleópteros (Insecta: Coleoptera) epígeos asociados al bosque maulino y plantaciones de pino aledañas. Revista Chilena de Entomología. 29, 9-18 (2003).

75. Doube, B. \& Schmidt, O. Can the abundance or activity of soil macrofauna be used to indicate the biological health of soils? in Biological Indicators of Soil Health (ed. Pankhurst, C. E) 265-295 (CAB International, 1997).

76. Borer, E. T., Briggs, C. J., Murdoch, W. W. \& Swarbrick, S. L. Testing intraguild predation theory in a field system: does numerical dominance shift along a gradient of productivity? Ecology Letters. 6, 929-935 (2003)

77. Arim, M., Marquet, P. A. \& Jaksic, F. M. On the relationship between productivity and food chain length at different ecological levels. The Am. Nat. 169, 62-72 (2006).

78. Folke, C. et al. Regime shifts, resilience, and biodiversity in ecosystem management. Annual Review of Ecology Evolution and Systematics. 35, 557-581 (2004).

79. Chazdon, R. L. et al. When is a forest a forest? Forest concepts and definitions in the era of forest and landscape restoration. Ambio. 45, 538-550 (2016).

80. Pickett, S. T. A. \& Cadenasso, M. L. The ecosystem as a multidimensional concept: Meaning, model, and metaphor. Ecosystems. 5, $1-10$ (2002).

81. Aslam, T. J., Benton, T. G., Nielsen, U. N. \& Johnson, S. N. Impacts of eucalypt plantation management on soil faunal communities and nutrient bioavailability: trading function for dependence? Biology and Fertility of Soils. 51, 637-644 (2015).

82. Naudts, K. et al. Europe's forest management did not mitigate climate warming. Science. 351, 597-600 (2016).

83. Lindenmayer, D. B. \& Franklin, J. F. Conserving forest biodiversity: a comprehensive multiscaled approach. (Island Press, 2002).

84. Lindenmayer, D. B. et al. Interacting factors driving a major loss of large trees with cavities in a forest ecosystem. Plos One. 7, e41864 (2012).

85. Horák, J. et al. Green desert?: Biodiversity patterns in forest plantations. Forest ecology and management. 433, 343-348 (2019).

86. Benra, F. et al. Ecosystem services tradeoffs arising from non-native tree plantation expansion in southern Chile. Landscape and Urban Planning. 190, 103589 (2019).

\section{Acknowledgements}

Constanza Schapeer from the Department of Entomology of the Metropolitan University of Education Science (UMCE, for its initials in Spanish), Santiago de Chile, for helping with invertebrate taxonomy. Francisca Campos, Francisca Campano, Benjamín Castro and Fabián González assisted with fieldwork. Fernando Alfaro made helpful observations and guiding to the statistical analysis. Funding was provided by the Instituto de Ecologia y Biodiversidad (IEB, for its initials in Spanish) through grant AFB170008 from CONICYT-Chile. The University of Chile funded the Internship for Research (2016-2017) at the University of Manchester. Richard Bardgett and the Soil Ecology Lab from the University of Manchester hosted the first author, supported laboratory analyses and provided useful discussion. Research in Los Ruiles National Park and Los Queules National Park was conducted with permission of the Chilean Forest Service (CONAF, for its initials in Spanish) under permit no 06-2015.

\section{Author contributions}

C. Cifuentes-Croquevielle, D. Stanton and J.J. Armesto conceived the study. C. Cifuentes-Croquevielle conducted field work and data collection. C. Cifuentes-Croquevielle and D. Stanton analysed the data. C. CifuentesCroquevielle, D. Stanton and J.J. Armesto contributed to writing the manuscript.

\section{Competing interests}

The authors declare no competing interests.

\section{Additional information}

Supplementary information is available for this paper at https://doi.org/10.1038/s41598-020-64453-y.

Correspondence and requests for materials should be addressed to C.C.-C.

Reprints and permissions information is available at www.nature.com/reprints.

Publisher's note Springer Nature remains neutral with regard to jurisdictional claims in published maps and institutional affiliations.

(c) (i) Open Access This article is licensed under a Creative Commons Attribution 4.0 International License, which permits use, sharing, adaptation, distribution and reproduction in any medium or format, as long as you give appropriate credit to the original author(s) and the source, provide a link to the Creative Commons license, and indicate if changes were made. The images or other third party material in this article are included in the article's Creative Commons license, unless indicated otherwise in a credit line to the material. If material is not included in the article's Creative Commons license and your intended use is not permitted by statutory regulation or exceeds the permitted use, you will need to obtain permission directly from the copyright holder. To view a copy of this license, visit http://creativecommons.org/licenses/by/4.0/.

(C) The Author(s) 2020 